\title{
Flood hazard assessment in large plain basins with a scarce slope in the Pampean Plain, Argentina
}

\author{
Guido Borzi (D) - Alejandro Roig • Carolina Tanjal • \\ Lucía Santucci • Macarena Tejada Tejada • \\ Eleonora Carol
}

Received: 3 September 2020 / Accepted: 2 March 2021

(C) The Author(s), under exclusive licence to Springer Nature Switzerland AG 2021

\begin{abstract}
Floods are one of the most common natural phenomena and represent a serious hazard when they affect human activities. Structural measures are commonly used to mitigate them; however, these do not always give good results, mainly in plain areas with scarce slope. In this sense, the generation of a flood hazard map contributes to adequate hazard management and disaster prevention. The aim of this work is to evaluate the flood hazard areas in hydrological plain basins with scarce slope, taking as a case study the Samborombón river basin located in the Pampean Plain, Argentina. For this, a flood hazard map was made based on the analytical hierarchy process and using a GIS, taking into account physical aspects of the terrain, observations, and field
\end{abstract}

G. Borzi $(\bowtie) \cdot$ C. Tanjal $\cdot$ L. Santucci $\cdot$ E. Carol Centro de Investigaciones Geológicas, CONICET-UNLP, Diagonal 113 n\#275, La Plata, Buenos Aires, Argentina e-mail: gborzi@fcnym.unlp.edu.ar

G. Borzi · C. Tanjal · L. Santucci · E. Carol Facultad de Ciencias Naturales y Museo, Universidad Nacional de La Plata, Av. 122 and 60, La Plata, Buenos Aires, Argentina

A. Roig

Departamento de Ciencias Basicas - Facultad de Ingeniería, Universidad Nacional de La Plata, Buenos Aires, Argentina

M. Tejada Tejada

Departamento de Geografía, Universidad Pablo de Olavide, Historia y Filosofía, Sevilla, España measurements. Likewise, the map was validated using satellite images and the inhabitants in danger in the basin were quantified. The results show that the flood hazard areas correspond mainly to the floodplain of rivers and tributaries, while the main and secondary divide zones have low flood hazard sectors. On the other hand, numerous urban settlements were identified within flood hazard areas, these being urban settlements in the vicinity of old urban centers and new gated communities with high value homes, quantifying 1961 inhabitants at flood hazard and showing poor territorial planning. The methodology proposed gives to the management agencies the possibility of generating land use maps, as well as designing mitigation and contingency plans after a large rainfall event.

Keywords Samborombón river basin · Urban settlements · Multi-criteria analysis · Analytical hierarchy process $\cdot$ GIS

\section{Introduction}

Floods are one of the most common natural phenomena and are a problem when they affect human activities (Dworak \& Görlach, 2005; Mogollón et al., 2016). Population settlements have been developed throughout the history in sectors where a close relationship with water bodies exists, and they have used the benefits of proximity to them for trade and/or 
supplies for diverse uses. However, population centers located close to water bodies are the most affected during large floods (Barry, 2007; Goff et al., 2010; Pacione, 1974; Villarrosa et al., 2009; Yeo \& Blong, 2010). The term hazard implies a situation in which a natural or human-induced phenomenon can produce losses (Smith, 2013). In this sense, the population growth and the expansion of the historical urban centers located in elevated riverine sectors, toward adjacent floodplain areas, leads to these new settlements being at flood hazard (Isunju \& Kemp, 2016; Mhonda, 2013; Montz, 2000; Morales, 2008). Floods produced by storm events have been documented in different sectors of the world associated with different terrains such as Asia, Europe, and North America, among others (Brooks \& Stensrud, 2000; Chau et al., 2013; Gaume et al., 2009; Maddox et al., 1980). There are records of large cities that have historically been affected by water excess (Barriendos \& Rodrigo, 2006; Burby, 2001; Carbognin et al., 2010; Montz, 2000); hence, mitigation strategies were used to avoid the recurrence of these events (Gentilomo \& Cecconi, 1997; Guerrero, 2013), mainly the construction of canals to evacuate the water excess (Cui et al., 2009; Scarpati et al., 2002).

The studies that define territory areas as hazardous are approached from different disciplines, such as approach through remote sensing (Hernández Guzmán et al., 2016), the use of land and activities that take place in it (Camarasa Belmonte et al., 2011; Frazier et al., 2010; Kourgialas \& Karatzas, 2011), or approaches mainly related to the vulnerability of flood hazard people (Camarasa Belmonte et al., 2011). Although the initial focus of these studies is different, they all have in common the aim to define hazardous areas to generate adequate management and territorial planning.

Global information systems (GIS) associated with flood hazards have been used in many parts of the world as the examples described above. The aim of these works is to generate maps that define hazards areas, giving a better impression of the spatial distribution of the hazard (Merz et al., 2007). These maps are generated using different techniques according to the data, characteristics, and information available in each territory. It is worth noting that many of these maps are generated with diverse information, among which historic flood zones stand out (Maantay \& Maroko, 2009; Merz et al., 2007), in which excellent results are obtained; however, this information is only available in developed countries. Despite this, other studies are based on the use of satellite images, rainfall or flow due to the lack of other base data, as usually occurs in countries of Latin America or Asia (Ho \& Umitsu, 2011; Chau et al., 2013; Hernández Guzmán et al., 2016). This context makes it evident that the same information is not always available in all areas to define sectors affected by floods, and hence it is necessary to use the available tools in each site.

The Buenos Aires province, located in the Pampean Plain in eastern central of Argentina (Fig. 1), is characterized by presenting a relief with a scarce slope of $0.1 \%$ (Sala et al., 1983), development of numerous rivers and streams, populated centers close to water bodies and agricultural activities in most of the territory. These characteristics make this sector to be known for its high agricultural productivity worldwide (Durán et al., 2011) as well as for the regular floods that affect the area (Latrubesse \& Brea, 2009; Scarpati \& Capriolo, 2013). Regular floods affect both the harvests in this province and the densely populated basins within it (Pedrozo \& Escobar, 2018; Reyna et al., 2007; Vázquez et al., 2009). The population development in these basins has been increased in recent years, and currently, some towns in the province have sectors with flood hazard, which have been historically affected by regular floods.

Given the recurrent flooding in the Buenos Aires province and the problems that this implies, some studies have been carried out to identify flood hazard areas (Hurtado et al., 2006; Quiroz Londoño et al., 2013); however, these studies are scarce and cannot always be applied to neighboring areas. This is because each author uses the data available from the basin to be studied, which may not be registered for the neighboring basins. For example, in Argentina, historical rainfall records were discontinued or interrupted in the 1990s with the closure of most of the railway stations where these data were collected. On the other hand, flows measurement is not uniformly distributed in the province and is only restricted to some rivers (Integrated Hydrologic Database, 2021) due to the lack of continuity of public policies that affect the organisms in charge of the registry. In this sense, conducting a study through them can lead to biased or wrong results. The available information and the characteristics of a specific area make each 


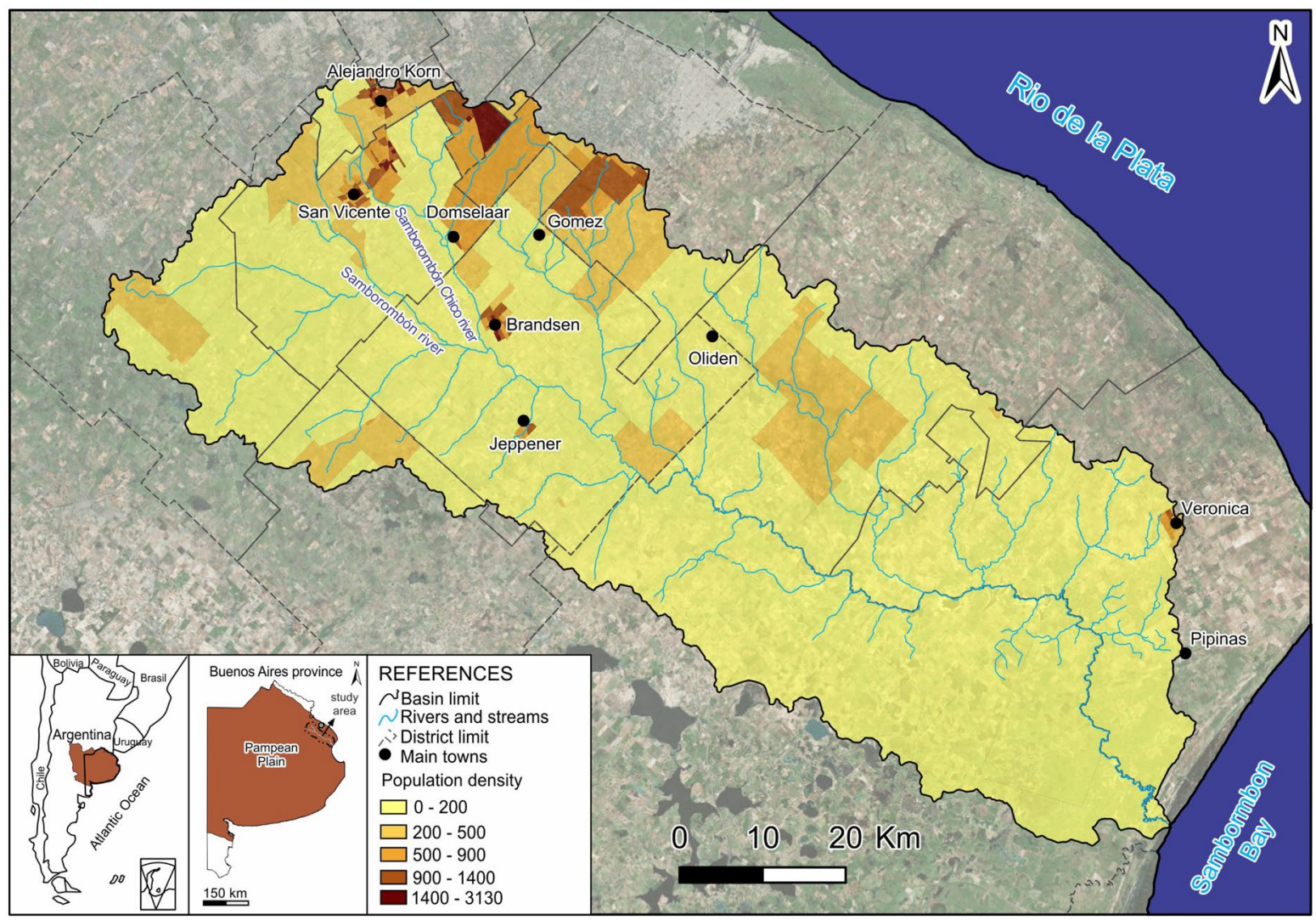

Fig. 1 Main populated sectors, population density, and location of the study area in the northeast of the Buenos Aires province, Argentina

site to be unique, being each one the starting point for the creation of a flood hazard map. Thus, defining a methodology to generate these maps is of utmost importance if representative results are to be achieved. Likewise, it is important to note that adequate flood management is mainly based on two factors; firstly, it is necessary to know the flood hazard areas, and secondly, it is essential to have a management strategy (Kourgialas \& Karatzas, 2011), being crucial the first factor for a proper territorial management.

The Samborombón river basin located in the northeast of the Buenos Aires province is in the context described previously and presents increasingly frequent flooding problematic. In this sense, this situation may be due to the occupation of flood hazard areas or due to the increase in rainfall registered in the region in recent decades (Borzi et al., 2020a; Kruse \& Laurencena, 2005). This basin has an extension of $5700 \mathrm{~km}^{2}$ and is characterized by a low slope of $0.18 \%$, where the water drainage after a large rainfall can take several days (Borzi, 2018). The basin is mainly rural, sparsely populated, and encompasses 12 districts, where crops, livestock, and population growth in recent decades predominate (INDEC, 2010). This population growth has been evidenced by the expansion of urban centers in the vicinity of the historical populated centers and the construction of gated communities in peri-urban areas (Borzi et al., 2020a). Likewise, some of these districts have a close relationship with Samborombón river or tributaries due to its proximity (Fig. 1), and several towns within these districts are the most affected during storm events.

The increase of population centers toward floodplain areas, added to the more frequent floods, evidences the need to generate flood hazard maps. However, the lack of data traditionally used for this type of study, such 
as flow data, is a limitation. The aim of the work is to assess the flood hazard in hydrological basins with scarce slope, taking as a case study the Samborombón river basin, located in the northeast of the Pampean Plain, Argentina. The methodology used in this work will not only be useful for the basin studied, but it may also be used in other basins with similar problems of hydrological data records, a characteristic which is shared by most developing countries.

\section{Materials and methods}

The flood hazard assessment in the Samborombón river basin was addressed by creating a hazard map using a multi-criteria analysis, since multiple factors interfere when a flood occurs. For this, physical aspects of the terrain were used, as well as observations and field measurements. Initially, variables that contribute to the presence of surface water after a large rainfall event were selected. Six variables were selected and incorporated into a GIS to be evaluated. These variables correspond to layers of slopes, soil permeability, flooding trend according to field observations, the thickness of the unsaturated zone, sinks, and finally a layer with the number of stream order applied to the subbasins. All the variables were valued and the methodology proposed by Saaty (1980) was subsequently used to form matrices of pairwise comparisons and normalize the variables. The analytical hierarchy process (AHP) is a multi-criteria decisionmaking technique that provides a systematic approach to assess the impacts of various variables (Saaty, 1980). The most common methodology used to make the comparison is the scale proposed by Saaty (1980). This consists of assigning a number from 1 to 9 to a variable, where 1 means equal importance between pairs of variables and 9 means that one variable is extremely more important than another; comparisons are always between pairs. The advantage of AHP is the possibility of combining data from different fields of knowledge, for example, management of watershed and natural resources, socioeconomic analysis, among others (De Steiguer et al., 2003; Jaiswal et al., 2014; Srdjevic, 2007).
To verify the discrepancy between the comparison of pairs of variables and the reliability of the weights assigned to them, the consistency ratio $(C R)$ may be calculated (Eq. 1), which must be $<0.1$ so that the weights assigned to the variables are accepted. Saaty (1980) proposes the following expression:

$C R=\frac{C I(A)}{R I n}$

where $C I(A)$ (Eq. 2) is the consistency index dependent on a comparison matrix A by pairs of variables, its elements are the relationship between two weights assigned to each one. $\lambda_{\max }$ is the maximum eigenvalue of the matrix $\mathrm{A}$ and $n$ is the dimension thereof. Also, $\lambda_{\max }=n$, if and only if matrix $\mathrm{A}$ is consistent and $\lambda_{\max }>n$ in the rest of the situations.

$C I(A)=\frac{\lambda_{\max }-n}{n-1}$

A $w=n \lambda_{\max }, w$ eigenvector. For the rest of the situations Saaty (1977) proposes a generalization and propose the following system:

$A w=\lambda_{\max } w$

There are also several methods for calculating the $w$ associated with the $\lambda_{\max }$, being used in this work the socalled eigenvector method, also corroborated from the "geometric mean method" proposed by Crawford and Williams (1985).

The RIn random index (Table 1) represents the consistency of a randomly generated pairwise comparison matrix. The RIn is derived as the average random consistency index, calculated by Saaty (1980), from a sample of 500 randomly generated matrices.

To assess the variables, seven matrices were used, one for each of the six variables, where the intrinsic differences of each one and a matrix were ranked where the different components were compared to give them a weight. The variables that were incorporated into the GIS have a scale of 1: 50,000 and were processed to obtain a flood hazard map of the same scale as a final result. The map was generated by calculating the sum of the variables previously multiplied by
Table 1 RIn random index values

\begin{tabular}{lllllllllll}
\hline Number & 1 & 2 & 3 & 4 & 5 & 6 & 7 & 8 & 9 & 10 \\
\hline RIn & 0 & 0 & 0.5247 & 0.8816 & 1.1086 & 1.2479 & 1.3417 & 1.4057 & 1.4499 & 1.4854 \\
\hline
\end{tabular}


their ranking. In this sense, each variable had different classes, which were ranked using the previously explained methodology (Saaty, 1980). The study area is a plain sector where the vertical movements such as evaporation and infiltration predominate over the horizontal movements (Auge \& Hernández, 1983; Forte Lay et al., 2007; Fuschini Mejía, 1983). All the water coming from the rainfall, which does not infiltrate and/ or evaporate, will tend to accumulate in topographically depressed sectors (sinks) or to drain, reason why the slope variable was considered. For the slope map, a digital terrain model (DTM) was used, which was created from the georeferencing of topographic charts of the National Geographic Institute (IGN) using the ANUDEM methodology developed by Hutchinson $(1988,1989,1996,2000)$. This choice is based on the fact that in areas with scarce relief such as the study area, slopes are overestimated in DEMs such as SRTM (Shuttle Radar Topography Mission) (Guth, 2006; Jarvis et al., 2004). Likewise, the choice of a DTM was due to the fact that this does not generate topographical super-elevations due to the constructions (Kiamehr \& Sjöberg, 2005; Schumann et al., 2008; Li \& Wong, 2010) or due to the presence of forestation (Carabjal \& Harding, 2006; Hofton et al., 2006; Presutti, 2009; Shortdrige \& Messina, 2011), a common characteristic in the farms of the basin, generating greater slopes or false divides (Valeriano et al., 2006) in plain areas. As mentioned previously, the vertical movements of water are predominant, which makes it necessary to consider the permeability variable, since it determines much of the water behavior after rainfall events. The soil cartography carried out by the National Institute of Agricultural Technology at a scale of 1: 50,000 (INTA, 1993) has the series of soils of each sector of the basin, as well as the percentage of each series that corresponds to each mapped polygon. The permeability values indicated in the soil series were normalized according to the infiltration rate. Although the previous hydraulic conditions of the soil determine an area flooding (Borzi et al., 2020b; Saksena et al., 2019), the incorporation of this parameter constitutes an areal characteristic that reflects the sectors with a different tendency to surface waterlogging. The infiltration rate parameters found in the soil charts of the basin are very slow, slow, moderately slow, moderate, moderately fast, and the value of this parameter acquired the higher number as the lower the infiltration rate is. On the other hand, the INTA series of soils (INTA,
1993) also includes field observations such as vegetation, terrain morphology that indicates its tendency to be flooded, spatial position with an exceptionally low tendency to flood, or observations regarding the water content of the soil such as excess moisture and conspicuous flooding, among others. This last variable was considered because on numerous occasions, these observations contemplate soil features that predispose, or not, the waterlogging of an area.

The depth of the water table obtained through field measurements and background information (Sala et al., 1972; CFI, 1980; Menéndez et al., 2010; Borzi, 2018), determines the thickness of the unsaturated zone. The water table variations respond mainly to seasonality, observing that during the months with less evapotranspiration, the water table rises slightly, a characteristic that makes this variable another factor that favors the presence of water on the surface (Borzi, 2018; Borzi et al., 2020b). In this variable, the lower thicknesses of the unsaturated zone were rated as more susceptible to flooding, due to the oscillation of the water table during the year and the possible rise of water table after storm events.

The development of the sinks is found throughout the basin; however, both in the headwaters and in the river mouth sector is where they are more evident. This variable was obtained using the DEM TandDEM-X $90 \mathrm{~m}$ downloaded from DLR's EOC GEOSERVICE (EOC Geoservice, 2019). The choice of this DEM was due to the fact that it is a product derived from an initial pixel of $12 \mathrm{~m}$ (Rizzoli et al., 2017; Wessel et al., 2018), and minor features can be observed which respond to the initial pixel size. In this sense, a preliminary analysis was carried out in the studied basin with different free access DEMs, being able to identify minor features with the TandDEM-X, but not with the SRTM or ASTER. The sink variable was filled using the ArgGIS 10.0 software, and afterward, the result was subtracted from the original DEM using map algebra, thus obtaining the areas where the sinks were found, considering these sectors with the highest category of flooding tendency.

Finally, using the ArcGIS 10.0 software and the TandDEM-X $90 \mathrm{~m}$, the Strahler (1954) order number of the drainage network was obtained. Due to the fact that minor features can be identified in the DEM used, the drainage network obtained could be observed even in sectors where the river has a width close to $15 \mathrm{~m}$, in the headwater area. In this sense, 
the lowest order number was found in the headwater sector, where the incipient streams are observed as continuous depressions and are born at the union of successive sinks. The value of the order number obtained was assigned to the subbasin where each course is located. It was considered that the subbasins that correspond to the higher order number, will accumulate water from those preceding, hence the subbasins with the highest order number will collect more water and will have a greater flooding tendency.

The variables were ranked using the matrices of pairwise comparisons and were incorporated into a GIS. Also, each variable was subsequently multiplied by its weight, adding up all the variables to obtain a final result, which was divided into five classes. Category 1 represents a very low potential for the pixel to be flooded, while category 5 has the highest potential for that pixel to be covered by water, finding categories 2, 3, and 4 with intermediate characteristics.

Satellite images of Landsat satellite from May 18 and 19,2000 , were used to validate the flood hazard map generated. The selection of these images was based on the fact that from the beginning of the Landsat satellite image captures (1972) until today, this series registered the greatest flooding in the basin during May 18 and 19, 2000. Likewise, the validation of the map generated was performed using the methodology proposed by Dey et al. (2019). In this sense, the areas with flood hazard obtained were compared with the flood registered in the Landsat image, where the value of $0 \%$ indicates that there is no correspondence between the generated model and the flooded area observed in the image, and the value of $100 \%$ indicates a good correspondence between them. Finally, the identification of urban settlements that are found in potentially flooded areas was carried out using Google Earth Pro software and, during fieldwork, an analysis of the constructions established in these areas was carried out. On the basis of this identification, the last censal radius of the 2010 population Census (INDEC, 2010) was used to quantify the inhabitants of the basin and to evaluate how many of them are located in flood hazard areas. It should be noted that after the year 2000, when the greatest flooding was recorded, there is an occupation of floodplain areas by the inhabitants through buildings (Borzi et al., 2020a), so a quantification of the inhabitants in floodplain areas could be performed for the census period.

\section{Results}

The matrix of pairwise comparisons enabled to assign a ranking to the variables, as well as the weight of each one. On the other hand, the values of consistency ratio $(C R)$ show that all the matrices made were accepted because they are below 0.1 (Satty, 1980) (Table 2). Likewise, there were no major differences between the eigenvector method and the geometric mean method.

The evaluation of the six variables used for the multi-criteria analysis showed that there is a great tendency for the floodplain of rivers and streams to be found as the feature that has greater susceptibility to flooding, and to a lesser extent there are sinks in areas without a connection to the drainage network (Fig. 2). The slope layer allowed the observation of the scarce slope of the rivers and streams floodplain limited by higher relative slopes sectors. Likewise, the highest sectors, in divide zones, are also characterized by a scarce slope, a common feature of this plain area (Fig. 2a). Regarding permeability, the lowest infiltration rate was observed mainly in the floodplain, as well as in sinks near the river mouth area. On the other hand, the highest infiltration rates coincided to a large extent with both main and secondary divide zones (Fig. 2b). The unsaturated zone presented the smallest thickness in the river mouth sector, as well as in river and streams floodplain, and progressively acquired the greater thickness in the main divide zone of the basin (Fig. 2c). Observations regarding the flood tendency of each soil evidenced to a great extent that the floodplain of rivers and streams are high susceptible, as well as the river mouth sector. Likewise, it was observed that streams in headwaters and sinks in the middle sector of the basin have a lesser tendency to flooding, finding the main and secondary divide zones with a low trend to flooding (Fig. 2d). The creation of the sink map allowed the delimitation of numerous sinks throughout the basin; however, its concentration was greater in the headwaters, divide zones and in the river mouth sector, coinciding with the lack of drainage integrated into the main network (Fig. 2e). Finally, the subbasins map where the order number of the streams was incorporated, allowed us to visualize that the main and secondary divide zones have a low order number, while the main floodplain has the maximum. It is highlighted that the intermediate orders are the minor tributaries, while the river 
Table 2 Weights and rankings obtained by the pairwise comparison matrices used in the GIS

\begin{tabular}{|c|c|c|c|}
\hline Variables/layers & Weighting & Classes & Ranking \\
\hline Slope & 0.278 & $\begin{array}{l}<0.0074 \% \\
0.0074-0.1926 \% \\
0.1926-0.3853 \% \\
0.3853-0.7171 \% \\
>0.7171 \% \\
\text { Consistency ratio } 0.0602\end{array}$ & $\begin{array}{l}0.5150 \\
0.2520 \\
0.1320 \\
0.0649 \\
0.0364\end{array}$ \\
\hline Infiltration rate & 0.202 & $\begin{array}{l}\text { Very slow } \\
\text { Slow } \\
\text { Moderate slow } \\
\text { Moderate } \\
\text { Moderate fast } \\
\text { Consistency ratio } 0.0152\end{array}$ & $\begin{array}{l}0.4190 \\
0.2630 \\
0.1600 \\
0.0973 \\
0.0618\end{array}$ \\
\hline Unsaturated zone & 0.196 & $\begin{array}{l}<1.4 \mathrm{~m} \\
1.4-1.9 \mathrm{~m} \\
1.9-2.5 \mathrm{~m} \\
>2.5 \mathrm{~m} \\
\text { Consistency ratio } 0.0433\end{array}$ & $\begin{array}{l}0.5650 \\
0.2620 \\
0.1180 \\
0.0550\end{array}$ \\
\hline Flood tendency & 0.124 & $\begin{array}{l}\text { High } \\
\text { Medium } \\
\text { Low } \\
\text { Scarce } \\
\text { Consistency ratio } 0.0367\end{array}$ & $\begin{array}{l}0.5990 \\
0.2590 \\
0.0980 \\
0.0440\end{array}$ \\
\hline Sink & 0.131 & $\begin{array}{l}\text { Without sink } \\
\text { With sink } \\
\text { Consistency ratio } 0\end{array}$ & $\begin{array}{l}0.1000 \\
0.9000\end{array}$ \\
\hline Subbasins with order number & 0.0693 & $\begin{array}{l}5 \\
4 \\
3 \\
2 \\
\text { Consistency ratio } 0.00538\end{array}$ & $\begin{array}{l}0.4830 \\
0.2720 \\
0.1570 \\
0.0880\end{array}$ \\
\hline
\end{tabular}

In this sense, a good correspondence is observed between the areas with the high flood hazard determined based on the multi-criteria analysis and the flooded areas recorded in May 2000 by the Landsat series (Fig. 3b). Thus, the validation of the generated map showed that $67 \%$ of the covers susceptible to flooding corresponded to flooding areas identified in the satellite image.

On the other hand, numerous sectors with urban settlements were identified in flood hazard areas, mainly associated with the floodplain of the river or tributaries, as well as some associated with topographically depressed sectors (Fig. 4). This enabled, using the censal radius, to quantify a total of 1961 inhabitants located in flood hazard areas, out of a grated into the main drainage is evident (Fig. 3a). 

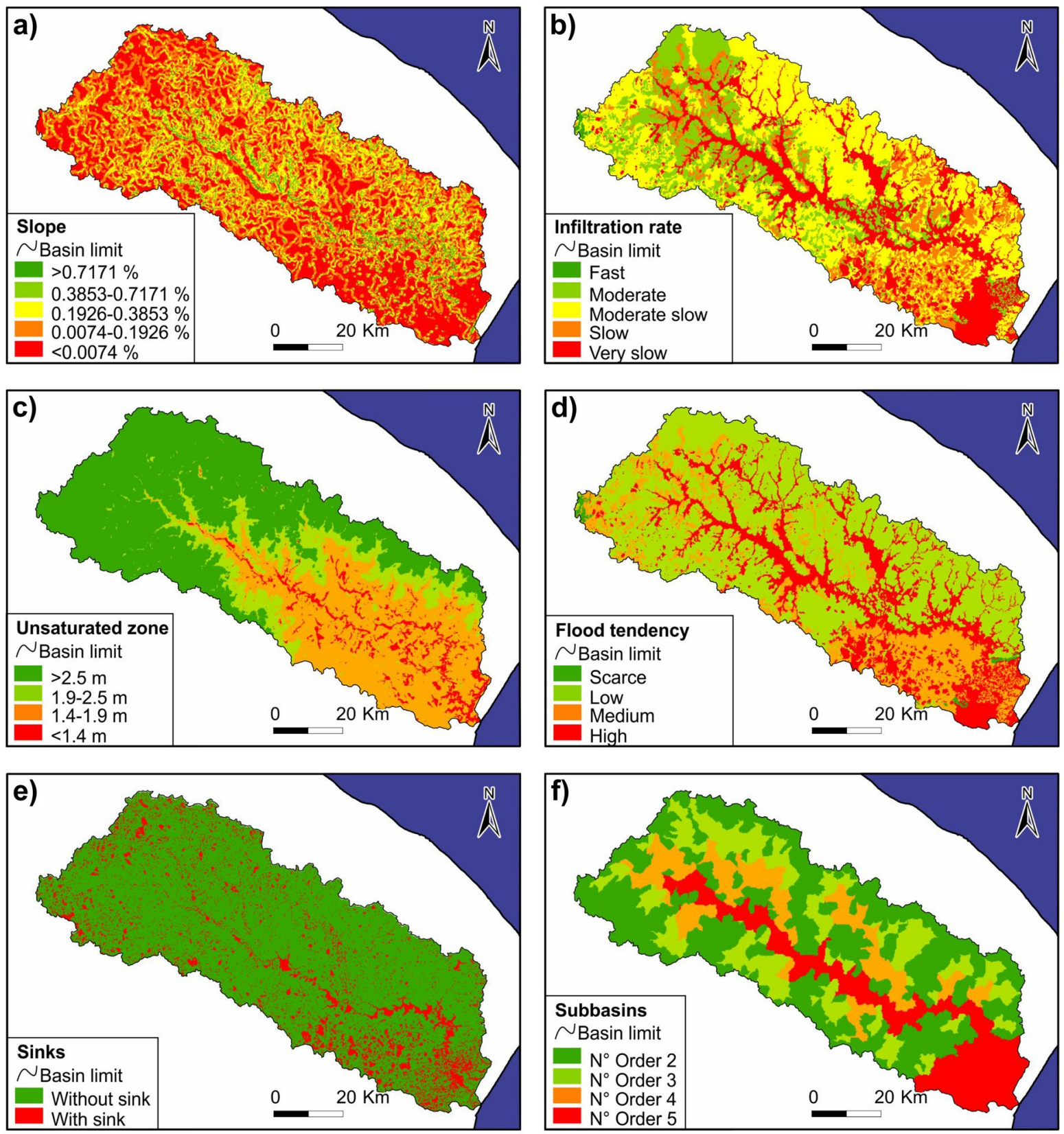

Fig. 2 Variables used in the AHP and GIS. a Slope. b Infiltration rate. c Unsaturated zone. d Flood tendency. e Sink. f Subbasins with order number

total of 184,590 inhabitants present in the basin, that is, approximately $1 \%$ of the total.

In this sense, ten sectors stand out for the higher population density. Of these, five areas correspond to urban settlements in the vicinity of old urban centers, which respond to the growth and expansion of the old historic centers (light blue circles in Fig. 4 and Fig. 5a-c). The remaining five sectors were identified as new gated communities, in rural peri-urban areas, evidencing a type of construction with great purchasing power (light blue squares in Fig. 4 and Fig. 5d-f). 


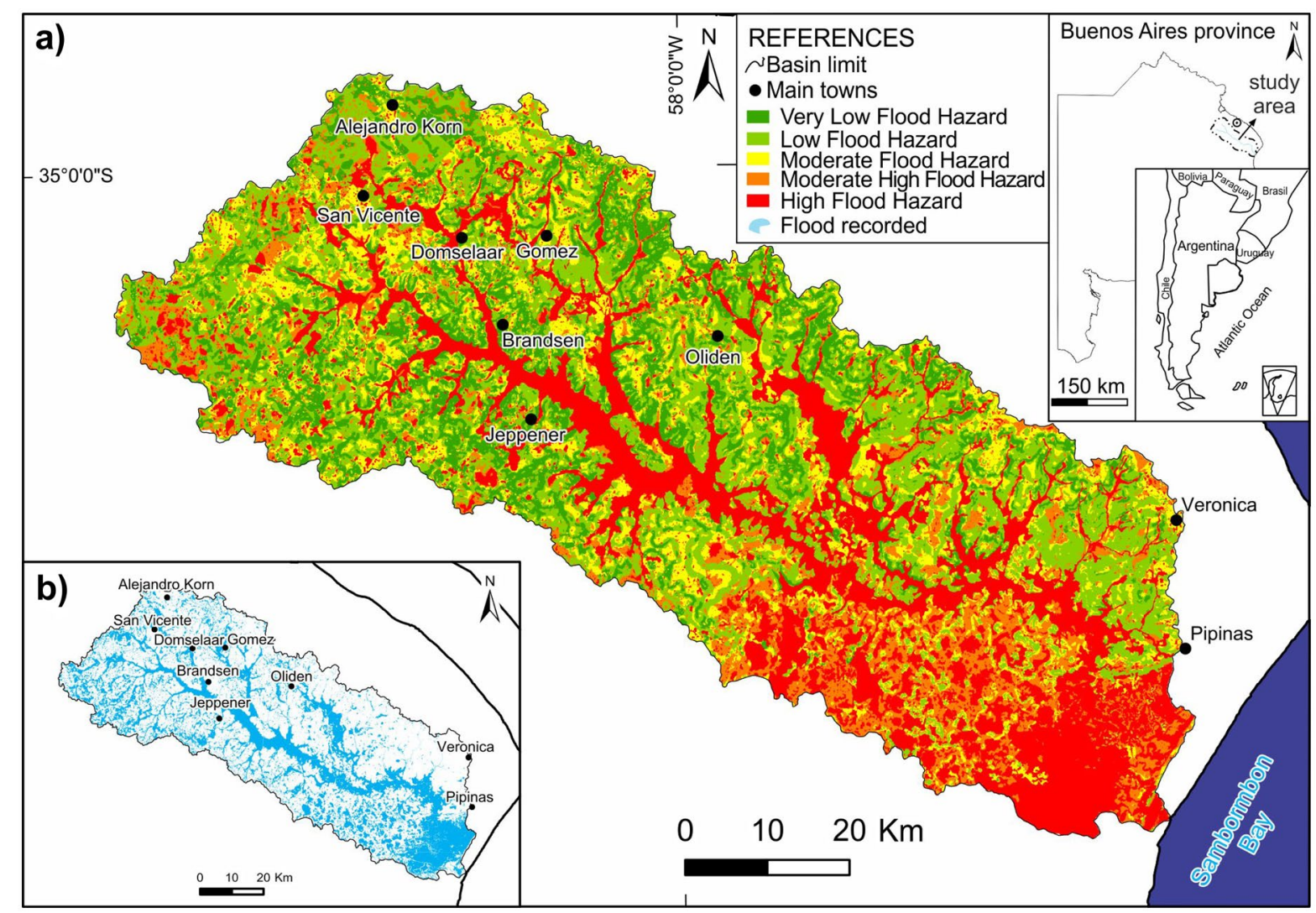

Fig. 3 a Flood hazard map generated based on multi-criteria analysis. b Flood classification from Landsat images recorded in May 2000

\section{Discussion}

The plain basin studied in this work is characterized by scarce to null hydrological information. Despite this, it was possible to select specific variables that allow to carry out a multi-criteria analysis and an evaluation of flood areas using a flood hazard map. Methodologies that use data of flows and/or historical floods are used in other regions (Maantay \& Maroko, 2009; Reyna et al., 2007); however, this information is not uniformly distributed both spatially and temporally throughout the world, nor is it available in the study area. Also, it is highlighted that multi-criteria analysis combined with GIS is a widely used methodology to create a flood hazard map, obtaining excellent results at different scales for different terrains (Youssef et al., 2011; Chen et al., 2015; Franci et al., 2016; Kazakis et al., 2015). In Argentina, studies aimed at identifying flood hazard areas are not very common (Esper Angillieri, 2012; Hurtado et al., 2006;
Peña-Monné et al., 2018; Quiroz-Londoño et al., 2013), and only a few authors have implemented the multicriteria analysis proposed by Saaty (1980) (Fernández $\&$ Lutz, 2010). Likewise, it should be noted that none of the studies has been carried out in a large plain basin with a scarce slope as that of the study area. Regarding the validation of the results obtained, it was corroborated that there is a good correspondence between the map generated based on the multi-criteria analysis and the flooded areas recorded by the Landsat series during the great flood in May 2000. This type of validation is not always carried out to define flood hazard areas (Bathrellos et al., 2016; Kourgialas \& Karatzas, 2011); however, they are important to give consistency to the methodology used. In this sense, the map generated highlights the maximum areas which tent to be flooded according to the physical characteristics of the terrain, being validated with the largest flood recorded. Although the variables considered contribute to the presence of 


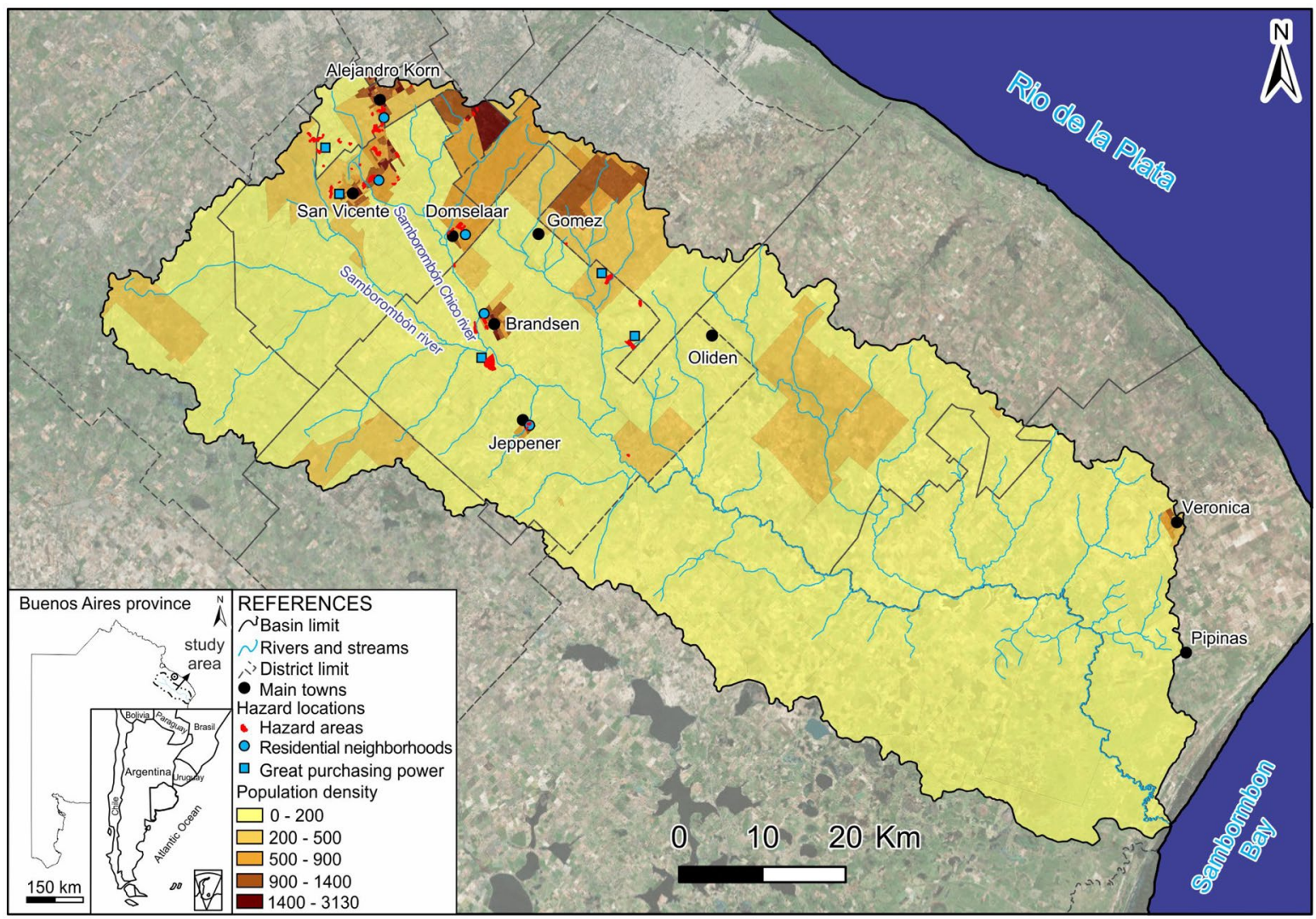

Fig. 4 Location of the main populated towns and flood hazard areas. Residential neighborhoods adjacent to populated towns are indicated in light blue circles; new gated communities with great purchasing power are indicated in light blue squares

Fig. 5 Urban growth in flood hazard areas at San Vicente district. a-c Urban settlements located east of the old urban center of San Vicente town. d-f Urban settlements located in a gated community in the peri-urban area west of San Vicente town

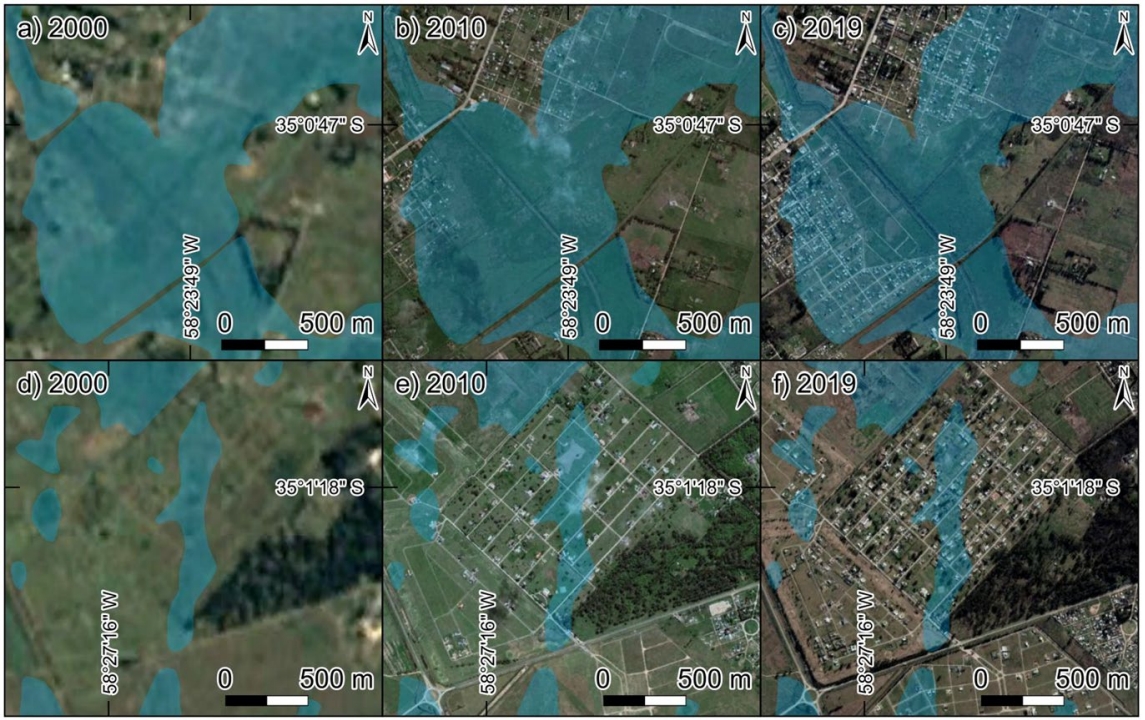


water on surface, the previous hydric conditions of the soil also do so (Wanders et al., 2014; Massari et al., 2014; Saksena et al., 2019), a situation that also has been documented in the studied basin (Borzi et al., 2020b). Despite this, there was no detailed information on where the floods occurred. In this sense, the areas may be smaller according to the flood event, which responds largely to the previous hydric conditions of the soil (Borzi et al., 2020b; Saksena et al., 2019). Despite the scarcity of flow data in the study area, hydraulic modeling in some sectors of the basin has shown a good correspondence with the map generated in this study (Borzi et al., 2020a). The creation of the flood hazard map shows that there are urban settlements that are susceptible to regular floods. The expansion of historic centers in the peri-urban sector has been carried out in areas without the conditions for urban development (Hernández-Guerrero et al., 2012). The generation of a flood hazard map constitutes one of the steps for proper hazard management and disaster prevention (González-Arqueros et al., 2018; Kourgialas \& Karatzas, 2011), contributing to the identification of potentially flooded areas, which can be early evacuated during major floods avoiding possible human losses. It is important to highlight that construction in areas with flood hazard in the Samborombón river basin does not respond to a particular social class since both residential houses and gated community with high purchasing power and buildings of great value were established within these areas. This situation is aggravated by the scarce slope of the study area, which makes it take several days for the water to drain after a storm event (Borzi, 2018). In this sense, the lack of planning management or, a territorial planning that carried out with scarce base studies is evident, a situation that is evidenced by the urban settlements in flood hazard areas at many parts of the world (Chang et al., 2009; Montz, 2000). It should be noted that currently, the urban settlements identified within flood hazard areas are in continuous growth (Borzi \& Carol, 2014), so there are more inhabitants at flood hazard than those quantified in 2010 when the population census was carried out.

Floods in Buenos Aires province affect agricultural producers (Latrubesse \& Brea, 2009; Tagle, 1980) and a great number of families located in flood areas (Clichevsky, 2006). Historically, the main mitigation measure for these floods was the construction of drainage canals. These structural measures do not always behave as expected (Camarasa Belmonte et al., 2011; Carol et al.,
2014) due to the fact that many parts of the province has an extremely flat relief and a terrain configuration that makes it impossible to drain all the water from the basins (Latrubesse \& Brea, 2009), and as a result, flood hazard areas continue flooding regularly. For this reason, defining flood hazard areas seems to be a low-cost and more urgent measure than using those that attempt to evacuate the water excess. Likewise, this study and future analyses in areas with this type of flood problematic are of vital importance for the development of environmental management guidelines and mitigation plans to avoid economic and human losses during and after major flooding.

\section{Conclusions}

Flood hazard is a serious problem in many regions around the world and especially in large plain basins with scarce slope. The expansion of urban centers through the construction towards flood areas within the hydrographic basins shows the lack of studies regarding areas suitable for urban development. Faced with the traditional and expensive structural measures that management agencies tend to adopt to drain the water excess, the generation of a flood hazard map is a low-cost task that allows identifying areas that are regularly flooded. In this sense, flood hazard maps, such as the one created in this work, enable the generation of land-use guidelines, evidencing the need to carry out this type of study prior to population development.

The methodology applied in this paper, allowed the generation of a flood hazard map from the scarce data available, also achieving its validation through remote sensing. It is worth noting that the analytical hierarchy process enables to give weights to the variables which can be accepted or rejected, reducing user errors.

The map presented in this study is an essential tool for management and territorial planning in the districts that constitute the basin, and it is also proposed as a methodology to use in plain basins such as those of the Pampean Plain. In this way, the proposed methodology provides the management agencies the possibility of generating land-use maps, as well as designing mitigation and contingency plans after a large rainfall event. 


\section{References}

Auge, M., \& Hernández, M. (1983). Características geohidrológicas de un acuífero semiconfinado (Puelche) en la Llanura Bonaerense. Su implicancia en el ciclo hidrológico de las Llanuras dilatadas. Coloquio Internacional sobre Hidrología de Grandes Llanuras. Actas (II): 1019-1041. Buenos Aires - París.

Barriendos, M., \& Rodrigo, F. S. (2006). Study of historical flood events on Spanish rivers using documentary data. Hydrological sciences journal, 51(5), 765-783.

Barry, J. M. (2007). Rising tide: The great Mississippi flood of 1927 and how it changed America. Simon and Schuster.

Bathrellos, G. D., Karymbalis, E., Skilodimou, H. D., GakiPapanastassiou, K., \& Baltas, E. A. (2016). Urban flood hazard assessment in the basin of Athens Metropolitan city. Greece. Environmental Earth Sciences, 75(4), 319.

Borzi, G., \& Carol, E. (2014). Identificación de áreas anegables y su vinculación con el crecimiento urbano en la cuenca del río Samborombón. II Jornadas Nacionales de Ambiente.

Borzi, G. E. (2018). Influencia de la actividad antrópica en la geohidrología de la cuenca del río Samborombón (Doctoral dissertation, Universidad Nacional de La Plata).

Borzi, G., Santucci, L., Tanjal, C., \& Carol, E. (2020a). Assessment of surface runoff conditioned by road works and urban settlements in large plain basins. Natural Hazards, 1-14.

Borzi, G., Cellone, F. A., Tanjal, C. V., Melendi, E. L., \& Carol, E. S. (2020b). Propuesta metodológica para el estudio de inundaciones en áreas de llanura con escasez de información. DYNA, 87(215), 221-228.

Brooks, H. E., \& Stensrud, D. J. (2000). Climatology of heavy rain events in the United States from hourly precipitation observations. Monthly Weather Review, 128(4), 1194-1201.

Burby, R. J. (2001). Flood insurance and floodplain management: the US experience. Global Environmental Change Part B: Environmental Hazards, 3(3), 111-122.

Camarasa Belmonte, A. M. C., López-García, M. J., \& SorianoGarcía, J. (2011). Mapping temporally-variable exposure to flooding in small Mediterranean basins using land-use indicators. Applied Geography, 31(1), 136-145.

Carabajal, C. C., \& Harding, D. J. (2006). SRTM C-band and ICESat laser altimetry elevation comparisons as a function of tree cover and relief. Photogrammetric Engineering \& Remote Sensing, 72(3), 287-298.

Carbognin, L., Teatini, P., Tomasin, A., \& Tosi, L. (2010). Global change and relative sea level rise at Venice: what impact in term of flooding. Climate Dynamics, 35(6), 1039-1047.

Carol, E. S., Braga, F., Kruse, E. E., \& Tosi, L. (2014). A retrospective assessment of the hydrological conditions of the Samborombón coastland (Argentina). Ecological Engineering, 67, 223-237.

Chang, H., Franczyk, J., \& Kim, C. (2009). What is responsible for increasing flood risks? The case of Gangwon Province. Korea. Natural Hazards, 48(3), 339.

Chau, V. N., Holland, J., Cassells, S., \& Tuohy, M. (2013). Using GIS to map impacts upon agriculture from extreme floods in Vietnam. Applied Geography, 41, 65-74.

Chen, H., Ito, Y., Sawamukai, M., \& Tokunaga, T. (2015). Flood hazard assessment in the Kujukuri Plain of Chiba Prefecture,
Japan, based on GIS and multicriteria decision analysis. Natural Hazards, 78(1), 105-120.

Clichevsky, N. (2006). Estado, mercado de tierra urbana e inundaciones en ciudades argentinas. Cuadernos de Geografia: Revista Colombiana de Geografía, 15, 31-52.

CFI. (1980). Estudio de la zona deprimida del Salado. Informe final ( $1^{\circ}$ Etapa).

Crawford, G., \& Williams, C. (1985). A note on the analysis of subjective judgment matrices. Journal of mathematical psychology, 29(4), 387-405.

Cui, B., Wang, C., Tao, W., \& You, Z. (2009). River channel network design for drought and flood control: A case study of Xiaoqinghe River basin, Jinan City. China. Journal of environmental management, 90(11), 3675-3686.

De Steiguer, J. E., Duberstein, J., \& Lopes, V. (2003). The analytic hierarchy process as a means for integrated watershed management. In First interagency conference on research on the watersheds (pp. 736-740). Agricultural Research Service, US Department of Agriculture, Agricultural Research Service, Benson, Ariz.

Dey, S., Saksena, S., \& Merwade, V. (2019). Assessing the effect of different bathymetric models on hydraulic simulation of rivers in data sparse regions. Journal of Hydrology, 575, 838-851.

Durán, A., Morrás, H., Studdert, G., \& Liu, X. (2011). Distribution, properties, land use and management of Mollisols in South America. Chinese Geographical Science, 21(5), 511.

Dworak, T., \& Görlach, B. (2005). Flood risk management in Europe@ the development of a common EU policy. International Journal of River Basin Management, 3(2), 97-103.

EOC Geoservice. (2019). "The Tandem-X 90m Digital Model”. Accessed 26 June 2019. https://geoservice.dlr.de/web/ dataguide/tdm90/

Esper Angillieri, M. Y. (2012). Morphometric characterization of the Carrizal basin applied to the evaluation of flash floods hazard, San Juan, Argentina. Quaternary international, 253, 74-79.

Fernández, D. S., \& Lutz, M. A. (2010). Urban flood hazard zoning in Tucumán Province, Argentina, using GIS and multicriteria decision analysis. Engineering Geology, 111(1-4), 90-98.

Forte Lay, J. A., Kruse, E., Aiello, J. L. (2007). Hydrologic scenarios applied to the agricultural management of the northwest of the Buenos Aires Province, Argentina. Geojournal, 70(4), 263-271.

Fuschini Mejía, M. C. (1983) Hidrología de Grandes Llanuras. Actas del Coloquio de Olavarría. PHI - UNESCO. Olavarría.

Franci, F., Bitelli, G., Mandanici, E., Hadjimitsis, D., Agapiou, A. (2016). Satellite remote sensing and GIS-based multi-criteria analysis for flood hazard mapping. Natural Hazards, 83(1), 31-51.

Frazier, T. G., Wood, N., \& Yarnal, B. (2010). Stakeholder perspectives on land-use strategies for adapting to climatechange-enhanced coastal hazards: Sarasota. Florida. Applied Geography, 30(4), 506-517.

Gaume, E., Bain, V., Bernardara, P., Newinger, O., Barbuc, M., Bateman, A., Blaškovičováf, L., Blöschlg, G., Borgah, M., Dumitrescui, A., Daliakopoulosk, I., Garciae, J., Irimescui, A., Kohnovaj, S., Koutroulisk, A., Marchil, L., Matreatad, S., Medinae, V., Precisol, E., ... Daliakopoulos, I. (2009). A compilation of data on European flash floods. Journal of Hydrology, 367(1-2), 70-78. 
Gentilomo, M., \& Cecconi, G. (1997). Flood protection system designed for Venice. Hydropower Dams, 2, 46-52.

Goff, J., Nichol, S., Chagué-Goff, C., Horrocks, M., McFadgen, B., \& Cisternas, M. (2010). Predecessor to New Zealand's largest historic trans-South Pacific tsunami of 1868AD. Marine Geology, 275(1), 155-165.

González-Arqueros, M. L., Mendoza, M. E., Bocco, G., \& Castillo, B. S. (2018). Flood susceptibility in rural settlements in remote zones: The case of a mountainous basin in the Sierra-Costa region of Michoacán, Mexico. Journal of environmental management, 223, 685-693.

Guerrero, M. C. (2013). Sevilla y Tamarguillo: Las medidas urbanisticas de urgencia cincuenta años después. Espacio y Tiempo: Revista de Ciencias Humanas, 27, 51-74.

Guth, P. L. (2006). Geomorphometry from SRTM: Comparison to NED: Photogrammetric.

Hernández-Guerrero, J., Vieyra-Medrano, A., \& Mendoza, M. E. (2012). Adaptation strategies in communities under precarious housing: flooding risks in the peri-urban sector of the city of Morelia, Michoacán, México. Applied geography, 34, 669-679.

Hernández Guzmán, R., Ruiz Luna, A., Berlanga Robles, C. A., \& Ponce Palafox, J. T. (2016). Analysis of flood pulse dynamics in the lower basin of the San Pedro River (northwestern Mexico) using remote sensing/Análisis de la dinámica de pulsos de inundación de la cuenca baja del Río San Pedro (México noroccidental) mediante teledetección. Latin American Journal of Aquatic Research, 44(2), 293.

Ho, L. T., \& Umitsu, M. (2011). Micro-landform classification and flood hazard assessment of the Thu Bon alluvial plain, central Vietnam via an integrated method utilizing remotely sensed data. Applied Geography, 31(3), 1082-1093.

Hofton, M., Dubayah, R., Blair, J. B., \& Rabine, D. (2006). Validation of SRTM elevations over vegetated and non-vegetated terrain using medium footprint lidar. Photogrammetric Engineering \& Remote Sensing, 72(3), 279-285.

Hurtado, M. A., Giménez, J. E., Cabral, M. G., Silva, M. D., Martinez, O. R., Camilión, M. C., Sánchez, C. A., Muntz, D., Gebhard, J. A., Forte, L., Boff, L., Crincoli, A., \& Lucesoli, H. (2006). Análisis ambiental del partido de La Plata. Aportes al ordenamiento territorial.

Hutchinson, M. F. (1988). Calculation of hydrologically sound digital elevation models. In: Proceedings of the third international symposium on spatial data handling.vol.133. International Geographical Union. Columbus.

Hutchinson, M. F. (1989). A new procedure for gridding elevation and stream line data with automatic removal of spurious pits. Journal of Hydrology, 106(3-4), 211-232.

Hutchinson, M. F. (1996). A locally adaptive approach to the interpolation of digital elevation models. In: Proceedings of the, third international conference/workshop on integrating GIS and environmental modeling. 21-26.

Hutchinson, M. F. (2000). Optimising the degree of data smoothing for locally adaptive finite element bivariate smoothing splines. ANZIAM J, 42, 774-796.

INDEC. (2010). Censo Nacional de Población Hogares y Viviendas. https://www.indec.gob.ar/indec/web/Nivel4-Tema-2-41-135

INTA. (1993). Cartas de Suelos de la República Argentina. ISSN 0327-781X. Centro de Investigaciones de recursos Naturales. Instituto de Suelos área de Investigación en Cartografía de Suelos y Evaluación de Tierras.
Integrated Hydrologic Database. (2021). http://bdhi. hidricosargentina.gob.ar. (Accessed 10 January 2021).

Isunju, J. B., \& Kemp, J. (2016). Spatiotemporal analysis of encroachment on wetlands: A case of Nakivubo wetland in Kampala. Uganda. Environmental monitoring and assessment, 188(4), 1-17.

Jaiswal, R. K., Thomas, T., Galkate, R. V., Ghosh, N. C., \& Singh, S. (2014). Watershed prioritization using Saaty's AHP based decision support for soil conservation measures. Water resources management, 28(2), 475-494.

Jarvis, A., Rubiano, J., Nelson, A., Farrow, A., \& Mulligan, M. (2004). Practical use of SRBM data in the tropics Comparisons with digital elevation models generated from cartographic data. Working Document no. 198, 32 pp. CIAT, Cali, Colombia.

Kazakis, N., Kougias, I., \& Patsialis, T. (2015). Assessment of flood hazard areas at a regional scale using an index-based approach and Analytical Hierarchy Process: Application in Rhodope-Evros region, Greece. Science of the Total Environment, 538, 555-563.

Kiamehr, R., \& Sjöberg, L. E. (2005). Effect of the SRTM global DEM on the determination of a high-resolution geoid model: a case study in Iran. Journal of Geodesy, 79(9), 540-551.

Kourgialas, N. N., \& Karatzas, G. P. (2011). Flood management and a GIS modelling method to assess flood-hazard areas - a case study. Hydrological Sciences Journal-Journal des Sciences Hydrologiques, 56(2), 212-225.

Kruse, E., \& Laurencena, P. (2005). Aguas superficiales. Relación con el régimen subterráneo y fenómenos de anegamiento. In Relatorio del XVI Congreso Geológico Argentino. La Plata, Argentina.

Latrubesse, E. M., \& Brea, D. (2009). Floods in Argentina. Developments in Earth Surface Processes, 13, 333-349.

Li, J., \& Wong, D. W. (2010). Effects of DEM sources on hydrologic applications. Computers, Environment and urban systems, 34(3), 251-261.

Maantay, J., \& Maroko, A. (2009). Mapping urban risk: Flood hazards, race, \& environmental justice in New York. Applied Geography, 29(1), 111-124.

Maddox, R. A., Canova, F., \& Hoxit, L. R. (1980). Meteorological characteristics of flash flood events over the western United States. Monthly weather review, 108(11), 1866-1877.

Massari, C., Brocca, L., Moramarco, T., Tramblay, Y., \& Lescot, J. F. D. (2014). Potential of soil moisture observations in flood modelling: Estimating initial conditions and correcting rainfall. Advances in Water Resources, 74, 44-53.

Menéndez, A. N., Badano, N. D., \& Re, F. (2010). Balance de agua subterránea en la cuenca del Matanza-Riachuelo mediante modelación numérica. Instituto Nacional del Agua.

Merz, B., Thieken, A. H., \& Gocht, M. (2007). Flood risk mapping at the local scale: concepts and challenges. In Flood risk management in Europe (pp. 231-251). Springer, Dordrecht.

Mhonda AIDAN. (2013). Evaluating flash flood risk reduction strategies in built-up environment in Kampala. University of Twente.

Mogollón, B., Frimpong, E. A., Hoegh, A. B., \& Angermeier, P. L. (2016). An empirical assessment of which inland floods can be managed. Journal of environmental management, 167, 38-48.

Montz, B. E. (2000). The generation of flood hazards and disasters by urban development of floodplains. Floods, 1, 116-127. 
Morales, A. P. (2008). Aumento del riesgo de inundación por ocupación indebida de las áreas de convergencia de aguas en el Sur de la Región de Murcia. Scripta Nova: revista electrónica de geografía y ciencias sociales, 12 .

Pacione, M. (1974). The Venetian problem: an overview. Geography, 59(4), 339-343.

Pedrozo, S. M., \& Eescobar, D. N. (2018). La Matanza y una constante: sus inundaciones. Actas Científicas CIG - $79^{\circ}$ Semana de la Geografía. 95-102.

Peña-Monné, J. L., Sampietro-Vattuone, M. M., Sánchez-Fabre, M., \& Bertini-Sampietro, M. S. (2018). Geomorphological dynamics and flood hazards of the Blanquito River (Tafí del Valle, NW Argentina). Journal of South American Earth Sciences, 86, 231-243.

Presutti, M. E. (2009). Comparación de un DEM generado a partir de curvas de nivel con el DEM-SRTM para estimar la altura de plantaciones forestales (pp. 2943-2950). Anais XIV Simpósio Brasileiro de Sensoriamiento Remoto.

Quiroz Londoño, O. M., Grondona, S., Massone, H. E., Farenga, M. O., Martinez, G. A., \& Martínez, D. E. (2013). Modelo de anegamiento y estrategia de predicción-prevención del riesgo de inundación en áreas de llanura: el sudeste de la provincia de Buenos Aires como caso de estudio.

Reyna, J., Spalletti, P., \& Brea, J. D. (2007). Riesgo de inundaciones en el Río Luján. In Tercer Simposio Regional sobre Hidráulica de Ríos.

Rizzoli, P., Martone, M., Gonzalez, C., Wecklich, C., Borla Tridon, D., Bräutigam, B., Bachmann, M., Schulze, D., Fritz, T., Huber, M., Wessel, B., Krieger, G., Zink, M., \& Moreira, A. (2017). Generation and performance assessment of the global TanDEM-X digital elevation model. ISPRS Journal of Photogrammetry and Remote Sensing, 132, 119-139.

Saaty, T. L. (1977). A scaling method for priorities in hierarchical structures. Journal of mathematical psychology, 15(3), 234-281.

Saaty, T. L. (1980). The analytic hierarchy process: Planning, priority setting. Resource Allocation.

Saksena, S., Merwade, V., \& Singhofen, P. J. (2019). Flood inundation modeling and mapping by integrating surface and subsurface hydrology with river hydrodynamics. Journal of Hydrology, 575, 1155-1177.

Sala, J.M., Ricoy, J., Ceci, J., Hernández, M., Mandel, J, Auge, M., Kersfeld, A., Filí, M., Temporetti, R., Vargas Aranibar, A., Rojo, A., \& Tomas, J. (1972). Contribución al conocimiento geohidrológico de la margen izquierda de la cuenca del Río Samborombón. Comité de Estudios de Aguas Subterráneas el Noreste.

Sala, J.M., Gonzalez, N, \& Kruse, E. (1983). Generalización hidrológica de la Provincia de Buenos Aires. Comité Nacional Para el Programa Hidrológico Internacional, H.G.LL/10/ TRA, Coloquio Internacional Sobre Hidrología de Grandes Llanuras, 11-20 Abril, 1983, Olavarría, pp 966-1009.

Scarpati, O. E., \& Capriolo, A. D. (2013). Sequías e inundaciones en la provincia de Buenos Aires (Argentina) y su distribución espacio-temporal. Investigaciones Geográficas, Boletín del Instituto de Geografía, 2013(82), 38-51.

Scarpati, O. E., Spescha, L., \& Capriolo, A. (2002). Occurrence of severe floods in the Salado river basin, Buenos Aires
Province, Argentina. Mitigation and Adaptation Strategies for Global Change, 7(3), 285-301.

Schumann, G., Matgen, P., Cutler, M. E. J., Black, A., Hoffmann, L., \& Pfister, L. (2008). Comparison of remotely sensed water stages from LiDAR, topographic contours and SRTM. ISPRS Journal of Photogrammetry and Remote Sensing, 63(3), 283-296.

Smith, K. (2013). Environmental hazards: assessing risk and reducing disaster. Routledge.

Srdjevic, B. (2007). Linking analytic hierarchy process and social choice methods to support group decision-making in water management. Decision Support Systems, 42(4), 2261-2273.

Strahler, A. N. (1954). Quantitative geomorphology of erosional landscapes. In CR 19th International Geological Congress, Algiers, 1952 (pp. 341-354).

Shortridge, A., \& Messina, J. (2011). Spatial structure and landscape associations of SRTM error. Remote Sensing of Environment, 115(6), 1576-1587.

Tagle, E. C. (1980). La inundación y sus efectos económicos en la explotación bovina en Dolores.

Valeriano, M. M., Kuplich, T. M., Storino, M., Amaral, B. D., Mendes, J. N., Jr., \& Lima, D. J. (2006). Modeling small watersheds in Brazilian Amazonia with shuttle radar topographic mission-90 m data. Computers \& geosciences, 32(8), 1169-1181.

Vázquez, P, Cabria F. N., Rojas M. D. C., \& Calandroni M.B. (2009). Riesgo de anegamiento: estimaciones para la cuenca baja del río Salado. Ciencia del suelo, 27(2).

Villarosa, G., Outes, V., Gomez, E. A., Chapron, E., \& Ariztegui, D. (2009). Origen del tsunami de mayo de 1960 en el Lago Nahuel Huapi, Patagonia: aplicación de técnicas batimétricas y sísmicas de alta resolución. Revista de la Asociación Geológica Argentina, 65(3), 593-597.

Yeo, S. W., \& Blong, R. J. (2010). Fiji's worst natural disaster: the 1931 hurricane and flood. Disasters, 34(3), 657-683.

Youssef, A. M., Pradhan, B., \& Tarabees, E. (2011). Integrated evaluation of urban development suitability based on remote sensing and GIS techniques: contribution from the analytic hierarchy process. Arabian Journal of Geosciences, 4(3-4), 463-473.

Wanders, N., Karssenberg, D., Roo, A. D., De Jong, S. M., \& Bierkens, M. F. P. (2014). The suitability of remotely sensed soil moisture for improving operational flood forecasting. Hydrology and Earth System Sciences, 18(6), 2343-2357.

Wessel, B., Huber, M., Wohlfart, C., Marschalk, U., Kosmann, D., \& Roth, A. (2018). Accuracy assessment of the global TanDEM-X digital elevation model with GPS data. ISPRS Journal of Photogrammetry and Remote Sensing., 139, 171-182.

Publisher's Note Springer Nature remains neutral with regard to jurisdictional claims in published maps and institutional affiliations. 